\title{
Forgiveness in Wives Experiencing Domestic Violence
}

\author{
Dewi Sartika and Nur Fadilah Amalia
}

\begin{abstract}
The aim of this study is to describe forgiveness and the factors contribute to it in wives experiencing domestic violence who choose to save their marriages in UPT-P2TP2A Kota Bandung. Descriptive method was employed in this study with 15 participants as the subjects. The data were gathered through forgiveness measurement adopted and based in the forgiveness theory proposed by McCullough. Its reliability score was 0,721 . The results of the study revealed that $73,3 \%$ of domestic violence victims who insist to save their marriages did forgive or gave for forgiveness. Among the factors determine the forgiveness, the low Rumination factor as well as high personal and moral commitment, encouraged a wife to forgive. Forgiveness showed by a wife, in some way impacted on the domestic violence doer. It lessened the intensity of the violence.
\end{abstract}

Index Terms-Forgiveness, domestic violence.

\section{INTRODUCTION}

The number of domestic violence or abusive cases towards wives in Indonesia is far above the ground. In the annual note of Woman National Commission, the total number of violence cases handled by this institution located in the 33 provinces in Indonesia reaches 119.107 cases in 2011 and 105.103 cases in 2010. This number increases from year to year. At least $11,4 \%$ or 24 millions of Indonesian women confess that they suffer from domestic violence [1]. The highest victim number in 2011 occurs in West Java. There were 17.720 cases noted in 2011. The cases range from domestic violence and community area to sexual abuse. The number is generated by 22 partner institutions in regions [2].

As the capital city of West Java, since 2002 in an effort of women crisis handling service in Bandung based on Puslitbang Gender and Children Research and Indonesia's State Minister of Women Empowerment Kajian Puslitbang, the goverment has formed an institution named P2TP2 (Integrated Service Center of Women Empowerment) Bandung. Along with the increasing level of domestic violence victims, in 2008 the Bandung Regional Goverment made P2TP2 to a more professional aim by the publication of Mayor Rule No. 265 dated 26 March 2008 becoming the Technical Implementation Unit (UPT) Integrated Service Center of Women and Children Empowerment (P2TP2A)

Since 2008, UPT-P2PTP has been dealing with about 236 violence case, 172 of them being a domestic violence case. As seen from the doer's and victim's point of view, the doer is usually the husbands, leaving the wife as the victim. Domestic violence most probably happens inside the marriage, one of them being the trust from the wife that it is

Manuscript received July 12, 2013; revised September 23, 2013.

Dewi Sartika is with the Bandung Islamic University, Indonesia (e-mail: dsartk@yahoo.com). his own right as the leader of the family. Educating the wife is an understanding that is being used most of the time as an excuse to hit, roughly warn, or scorn, and other kinds of behavior that can hurt the wife, physically and mentally.

There are two possibilities of wives that experienced domestic violence. Which are to divorce, or to maintain her marriage. Out of 172 cases of domestic violence that were handled by P2TP2A Bandung, 60 of them chose to maintain their marriage. According to researcher's interview to 3 wife victims of domestic violence who complained to UPTP2TP2A Bandung, they have been experiencing domestic violence for years in their marriage and wanting to maintain it. Some of them said that they are desperately helpless to solve their problem by telling it to their own family. They came to P2TP2A as a neutral side hoping to get the solution for their problem. They appear to have various kinds of physical and psychological condition. Then, they feel unable to do an action towards their husbands, crying as they hardly tell their story, and some of them even felt burdened as they do their daily activities.

Based on the results of the interview to the Chief of P2TP2A Bandung, the wives that chose to maintain their marriage despite of experiencing domestic violence, had certain factors that underlie it. Among those factors is religious factor. That wife prefers to be sincere in facing and coping with the domestic violence as an ordeal from God. Then, the following factors are financial, children, extended family and the positive wish that the husband will not do the violence again in the future.

A wife, who is continuously being exposed to the cycle of domestic violence, can affect herself, her children, or even her environment. The effect she carries is extremely hard because the violence can be a traumatic experience to her. Therefore it can cause not only short- term effect but it is also able to create long-term effect. Physical effects of domestic violence can be various such as physical wound and physical deformity. Besides, it can also cause psychological effects such as anxiety, worry, depression, self- esteem loss and reserve. The violence can affect the socialization as well. The victims can receive certain stigma from the society and get accused by the family and so on [3].

Wives experiencing domestic violence, along with the effects they suffer from, will go through negatively emotional experience, grudge, hatred, fear which are usually called unforgiveness. Reference says unforgiveness as a combination of delayed negative emotions (i.e., resentment, bitterness, hostility, hatred, anger, and fear) toward a transgressor. We view unforgiveness essentially as stress response with potential health consequences [4]. After experiencing unforgiveness, someone should necessary consider forgiveness as an effort to wipe unforgiveness and to make peace with themselves and the person violated them. Forgiveness is something very important but hard to do at the same time and it is supported by various factors [5]. 
In some cases noted in P2TP2A Bandung, some wives insist on maintain their marriages try to burry domestic violence they experienced and struggle to positively behave to their husbands. Nevertheless, there are some wives who keep blaming their husbands and keep talking about the violence she experienced. They became worried and do not benefit from their marriages although they confess that they have already forgiven and want to maintain the marriages. References have both conceptualized forgiveness in terms of a change in motivations, and primarily on the context of close relationship. Forgiveness in this context has been conceptualized as a desire in motivation to avoid and retaliate against the wrongdoer and an increase in motivation to respond in prosaically ways [6].

Forgiveness is a change process by which an individual becomes more positively disposed and less negatively disposed toward an individual who has harmed him or her at some point in the past [7]. Forgiveness is capable of having positive effects in life quality, gratitude, optimism, optimism, and trust. Besides, it also has negative effects toward emotional distress and other negative statement of feelings such as depression, anger, anxiety, and revenge, worry, guilty and easier to be infected by a disease [8]. Eventually, forgiveness can improve somebody's physical health and psychological welfare and improve interpersonal relationship, especially between the wives and the husbands. Through forgiveness, hopefully, the violence done by the husbands can lessen and the relationship among the individuals within a family will be happy in harmony [9].

The aim of this study was to know the description of forgiveness and certain factors determined it in the wives victims of domestic violence who preferred to maintain their marriages in UPT P2TP2A Bandung. Some factors determining forgivenss that this study wanted to explore were Rumnation. It refers to victims' tendency to continuously memorize the event that can trigger anger and prevent themselves from forgiveness and personal commitment quality, in this case marriage, is a personal intention to struggle in a relationship, a moral obligation to maintain the relationship and the insistence from third party to leave the relationship. The results of this study are hopefully able to benefit to wife victims in relation to forgiveness toward their spouse who are also the doers of domestic violence. By doing so, hopefully the wives can get better psychological welfare, physical health and interpersonal relationship. Besides, this research is also expected to be useful for UPT-P2TP2A to give insight on forgivenss in private counseling done to the wife victims.

\section{METHOD}

This study employed descriptive method which attempted to illustrate and interpret forgiveness in wives experiencing domestic violence who insisted to maintain their marriages in UPT P2TP2A Bandung. The participants in this study were women who were the victims of domestic violence in the age of their marriage and decided to maintain it which was still being handled by UPT P2TP2A Bandung. There were 15 cases during 2010-2012. In this study, all the populations were used as the subjects.

The measurement employed was Transgression-Related
Interpersonal Motivations Scale (TRIM-18 scale). It is scale developed by Micheal E. McCullough and used to identify the extent of somebody's forgiveness [10]. This scale was stated by questions and responses ranged from 1 to 5point (five point continuum). The components developed by Michael E. McCullough consist of 3 elements, those are: (1) avoidance motivations which is defined as avoidance motivation toward the guilty, (2) revenge motivation that is the motivation to revenge, and (3) benevolence motivations which means benevolence motivation. There was also other measurement used to see the factors contributing to forgiveness as secondary data that is Rumination About an Interpersonal Offense scale (RIO) created by Nathaniel G.Wade (2007) [11]. It consist of six items to measure the wives tendency which kept memorizing painful events, and Components of Commitment Scale made by Johnson et al., (1999) which consist of 49 items to measure marriage commitment [12].

The data analysis technique used in this study was descriptive statistic which employed percentage as its statistic method (\%). To identify how many respondents who have forgiveness (percentage) along with the high or low aspects of forgiveness, thus categorization based on the normal distribution was done.

\section{RESUlT AND DISCUSSION}

Based on the data processing of each subject, the following result regarding forgiveness in wife victims is revealed as follows.

TABLE I: THE PERCENTAGE OF FoRgIVENESS IN WIFE VICTIMS OF

\begin{tabular}{|c|c|c|}
\hline \multicolumn{3}{|c|}{ DOMESTIC VIOLENCE } \\
\hline Kategori & $\begin{array}{c}\text { Victim total } \\
\text { number (wives) }\end{array}$ & $\%$ \\
\hline Forgiveness & 11 & $73,3 \%$ \\
\hline Unforgiveness & 4 & $26,7 \%$ \\
\hline Total & 15 & $100 \%$ \\
\hline
\end{tabular}

References defines forgiveness as the change of a series of behavior in which a motivation decrease to stay themselves away from the doers (avoidance motivation), the motivation decrease to revenge (revenge motivation) (revenge motivation) and the existence of the increase motivation or willingness to make peace and do positive things (benevolent motivation) with the doer [13]. Table I shows that there are 11 wife victims $(73,3 \%)$ who forgave and the other $4(26,7 \%)$ didn't forgive.

The following chart describes the profile of the 3 aspects of forgiveness toward the subjects, both forgiveness and unforgiveness.

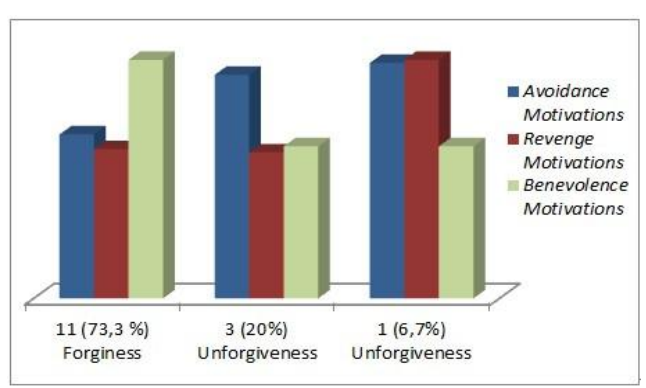

Fig. 1. The profile of forgiveness aspects, in both forgiveness and unforgiveness wives. 
The Fig. 1 explains that the majority of wife victims $(73,3 \%)$ did the forgiveness and by forgiving they could understand the reasons why the husbands did the violence. They knew what make the husband furious and acted violently. They tried to excuse the situations and attempted to stay away from what their husbands hated. They did accept the situation sincerely and kept being patient and behaved well. They were still grateful and were able to see some positive sides from what the husbands have done to them. In addition, they hoped that their sincerity would get the husbands' behavior better. Based on the interview result, by forgiving, indirectly affect to lessen the frequency of the violence done by the husbands so their relationship as a spouse was getting better.

Meanwhile, among the 4 wives who didn't forgive, although they maintain their household;

3 of them had the tendency to stay away and avoid their husbands both physically and psychologically (with high revenge motivation). They would do nothing when they got abusive action from their husband. They would find a way to go away from their husband. This wouldn't fix anything, because when the wives stayed away, they would tell their husbands' foul to other people or they would repress their feeling and this would lead to other physiological or physiological effects. Although they maintain their household, but deep inside it wasn't followed by selfacceptance and forgiveness. This kind of this would result on much worse situation in the future.

And, the other 1 had the motivation to revenge (high revenge and benevolent). With this motivation, the wives would feel so tortured although they maintained their household. She sacrificed their feeling to something she regarded more important, in this case prioritizing norms and value in her environment that made divorce impossible to happen. Wives would do nothing when their husband performed abusive behavior. Nevertheless, in their heart they have a motivation to revenge and probably they will hurt their husband some day in the future. Not to forgive is actually something bad for them.

This kind of thing of course made the situation in the household become uncomfortable and unhealthy psychologically both for the wife and for their children.

As the secondary data, here is the description/the rumination percentage of the wife victims.

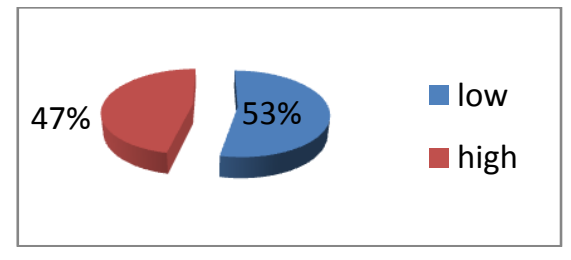

Fig. 2. Rumination percentage.

Based on the Fig. 2, it can be concluded that there were 8 wives $(53 \%)$ out of 15 who had low rumination level. It means that they did not want to recall painful memories and the violence they experienced. It is enough for the victims to feel the pain when the action took place for the next they preferred to see the future. On the other hand, there were 7 $(47 \%)$ other who still recalling the painful events. This kind of thing pisses off and haunts their minds. By remembering that thing, they hurt themselves and suffered from it. It was hard for them to avoid bad things that have been done by their husband. This situation created unpleasant situation as long as they maintained their household.

Below is the matrix of forgiveness with the rumination:

TABLE II: FORGIVENESS MATRIX AND THE RUMINATION OF WIFE VICTIMS

\begin{tabular}{|l|r|c|c|c|}
\hline & \multicolumn{2}{|c|}{$\begin{array}{c}\text { High } \\
\text { Rumination }\end{array}$} & \multicolumn{2}{c|}{ Low Rumination } \\
\hline & Total & $\%$ & Total & $\%$ \\
\hline Forgiveness & 3 & 20 & 8 & 53 \\
\hline Unforgiveness & 4 & 27 & 0 & 0 \\
\hline
\end{tabular}

Based on the Table II, there were 3 people who did forgiveness but having the high level of rumination in the same time. It means, although they forgave but the bad memories still lingered on their mind. Although they tried hard to forgive, but they still couldn't forgive sincerely and avoid the thought and imagination about the violence their husbands performed. Meaning, even though they attempted to be sincere, thought positively and kept on being patient in that situation, they tried to understand their husband situation that hurt them. Actually, the memory of violence did by their husband still haunted them. It was hard for them to hide from that memory. This situation will disturb their mental health.

The description of marriage commitment in wife victims:

TABLE III: THE PROFILE OF MARRIAGE COMMITMENT IN WIFE VICTIMS

\begin{tabular}{|l|l|c|c|}
\hline $\begin{array}{l}\text { Forgiveness/ } \\
\text { unforgiveness }\end{array}$ & $\begin{array}{l}\text { Component of } \\
\text { Commitment }\end{array}$ & Total & $\%$ \\
\hline \multirow{2}{*}{ Forgivenes } & $\begin{array}{l}\text { Personally, morally \& } \\
\text { structurally high }\end{array}$ & 5 & $33 \%$ \\
\cline { 2 - 4 } & $\begin{array}{l}\text { Personally, morally } \\
\text { high }\end{array}$ & 6 & $40 \%$ \\
\hline Unforgiveness & $\begin{array}{l}\text { Morally, structurally } \\
\text { high }\end{array}$ & 3 & $20 \%$ \\
\cline { 2 - 4 } & Morally high & 1 & $7 \%$ \\
\hline
\end{tabular}

Based on the Table III, it is revealed those who forgive (5 people) did the forgiveness because of their high personal, moral and structural commitment and six of them did that because of their high personal and moral commitment. If it is combined, all of the wives who forgave had high moral and personal commitment. It means, they maintain their marriages and did want to forgive although they experienced domestic violence because of love and religious norm and some values about the purity of a marriage. They tried to be happy in that situation and accepted it because she didn't think that she violate either social norms or the purity of her household. Meanwhile, those who did not forgive but still maintained their marriages, they did that because of their high moral and structural commitment. It means, they left their marriages or divorced, they felt that they have already violated the purity of the marriages and religious norms as well as the values they believed. They would feel sinful if they divorced and wouldn't be peaceful if they performed sinful actions. In other words they will get embarrassed in front of the society.

\section{CONCLUSION}

Based on the result that was gathered from data 
processing and study of 15 wife victims of domestic violence that kept their marriage at UPT P2TP2A, it can be concluded as follows:

1) As many as $73,3 \%$ or 11 wife victims of domestic violence that maintain their marriage admitted that they forgive their husbands. This was indicated by high benevolence motivations and low revenge motivations.

2) Social-cognitive factor is indicated by the existence of low rumination in most wife victims of domestic violence who has done forgiveness which is $53,3 \%$ or 8 wives. While the other 3 was still having a high amount of rumination. It means that although they forgave, but deep inside it was not easy for her to forget the violence did by her husband. It lingered although they tried had to be sincere.

3) Relationship Quality Factor is indicated by all the wives who forgave because of high personal and moral commitment.

4) Unforgiveness done by $27 \%$ of wives was based on high moral commitment. In other words, they maintained their household because of high normative value.

Some suggestions that can be given to wife victims of domestic violence or P2TP2A itself are as follows:

1) It is better for the wife victims of domestic violence who are unforgiving to train themselves and learn how to decrease the desire to avoid or even to avenge. It is due to the fact that forgiveness can give psychological health and welfare, and fix interpersonal relationship.

2) It is encouraged for the wives that has done forgiveness but keep remembering the events (high rumination) to take a blessing in disguise from the conflict and the violence that the husbands have done so they can forgive their husbands sincerely.

3) It is encouraged for UPT P2TP2A Bandung to be able to give private counseling to those who are forgiving, with neurotic personalities, and with high rumination. It is also recommended for those who are unforgiving to attend private. Because if the wives can survive in their marriages but can't forgive it will damage both their physic and mental health.

\section{REFERENCES}

[1] Indonesia News. (July 08, 2001). Domestic Violence Must Be Stopped. [Online]. http://www.library.ohiou.edu/indopubs/2001/07/08/0035.html.
[2] Kompas, Regional Rule Discrimination to Woman Increases, October 24, 2012.

[3] M. H. Soeroso, Domestic Violence, Jakarta: Sinar Grafika, 2010.

[4] E. L. Worthington, Handbook of Forgiveness, New York: Routledge Taylor \& Francis Group, 2005, pp. 321.

[5] M. E. Cullough, K. C. Rachal, and S. J. Sandage, Interpersonal Forgiving in Close Relationships: Theoretical Elaboration and Measurement, American Psychological Association, Inc., 1998.

[6] D. A. Owen, A Cross-Cultural Study of The Concept and Process of Forgiveness, University of Wisconsin of Madison, 2008, pp. 11.

[7] M. E. Cullough, Writing about the Benefits of an Interpersonal Transgression Facilitates Forgiveness, Miami: University of Miami, 2006, pp. 867.

[8] E. L. Worthington, Handbook of Forgiveness, New York: Routledge Taylor and Francis Group, 2005, pp. 322-327.

[9] E. L. Worthington, Handbook of Forgiveness, New York: Routledge Taylor and Francis Group, 2005, pp. 185-188.

[10] B. A. Tabak and M. E. McCullough, "Conciliatory gestures facilitate forgiveness and feelings of friendship by making transgressors appear more agreeable," Journal of Personality, Wiley Periodicals, pp. 507 , 2012.

[11] N. G. Wade, Measuring State-Specific Rumination: Development of the Rumination about an Interpersonal Offense Scale, Iowa State University, 2008

[12] N. L. Bartsch, "An association of commitment and communal and communal-exchange relationship orientation," Texas: Texas Tech University (Dissertation), 2005.

[13] J. S. Lopez and C. R. Snyder, Positive Psychology Assessment, Washington DC: American Psychological Association, 2004, pp. 303.

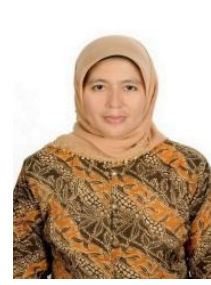

Dewi Sartika was born in Bandung, August 161965 Earning Bachelor degree of psycology in 1991 at Bandung Islamic University then she continued to Master of Science in Psychology, in 2003 at Padjajaran University and completing Doctor Program of Industry Psychology at Padjajaran University. She works as a psychology lecturer, at Bandung Islamic University. She teaches Psychometry, Research Methods, Career Guidance, Graphic Test, and Psychology Interview. Besides teaching, she is active as a speaker in some events such as talk show about education and development and marriage problems in locally private TV station, speaker in seminar regarding counseling and guidance as well as marriage problems.

She is a member in Indonesian Psychology Association (HIMPSI), Industry and Organization Psychology Association (APIO) and Indonesian Developmental Psychology Association (APPI).

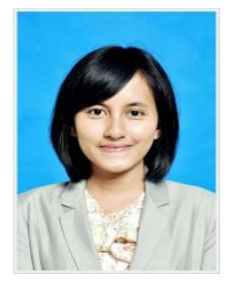

Nur Fadilah Amalia was born in Bandung, September 16 1991. She is now an $8^{\text {th }}$ semester student majoring psychology in Bandung Islamic University. She is active as a volunteer for KPSI (Komunitas Peduli Schizophren Indonesia) Bandung and as a reader in Wyata Guna. 